\title{
Image analysis and health of Moringa oleifera seeds
}

\author{
Michelle Conceição Vasconcelos ${ }^{*}$, Joel Conceição Costa', \\ Renata Silva-Mann', Andréa dos Santos Oliveira², \\ Cláudio das Neves Vieira Bárbara², Maria Laene Moreira de Carvalho ${ }^{3}$ \\ 'Federal University of Sergipe, São Cristovão, Brazi \\ ${ }^{2}$ State University of Mato Grosso, Cáceres, Brazil \\ ${ }^{3}$ Federal University of Lavras, Lavras, Brazil \\ *Corresponding author, e-mail: michelle_florestal@yahoo.com.br
}

\begin{abstract}
Moringa oleifera Lam. (moringa) is a tree species with the potential for use in biofuel production. However, knowledge regarding the morphology and physiology of its seeds is needed to establish field production. The goals of the present study were to investigate the internal morphology of seeds by X-ray and to identify the fungal microorganisms present in the seeds. Two hundred seeds from two trees were analyzed. The morphological characterization of the seeds was performed using an X-ray chamber with an X-ray source operated at $22 \mathrm{kV}$ for $14.8 \mathrm{~s}$. The fungi were identified using the blotter test. The seeds were characterized as (a) full and well formed, (b) with internal space and poorly formed and (c) stained or damaged. The malformed seeds with an internal space showed the highest incidence (55\%). The results indicated that X-ray tests are valid for the internal characterization of moringa seed morphology. The fungi Aspergillus niger, Aspergillus flavus, Alternaria sp., Fusarium sp., Penicillium sp. and Phomopsis sp. occurred in moringa seeds.
\end{abstract}

Keywords: blotter test, germination, Moringaceae, morphology

\section{Introduction}

Moringa oleifera L. is a fast-growing, drought tolerant tree which has recently been identified as one of the prospective sources of biodiesel and one of the plants which can play a prominent role in the fight against desertification (Mirhashemi et al., 2018).

There is an increasingly demand for alternative vegetable oils sources. Over the last decade there has been fast growing interest in $M$. oleifera, particularly due to its high seed oil yield (30-40\%), while other Moringa species with similar potentialities are reducing their representativeness worldwide. The interesting composition of Moringa oil, rich in oleic acid and highly resistant to oxidation, for industrial purposes. Exploring adapted varieties or producing interspecies hybrids can create added value to these less explored species, while renewing attention to endangered species. Moringa seed oil can be extracted by conventional methods or using physical methods (pressing), creating diverse products from a compositional perspective, able to serve both the biodiesel and food industries (Boukandoul et al., 2018).

All Moringa trees bear long pods (fruits) in variable numbers, containing up to 20 seeds each. The number of pods per $M$. oleifera tree differs between accessions, ranging from 10 to 62, with different seed weights (between 
$25.5 \mathrm{~g}$ and $37.3 \mathrm{~g}$ for 100 seeds). The effective seed productivity is dependent not only upon the species/varieties, but also on cultivation techniques, soil and climate, and the seed analysis can be utile for seed selection aiming to stablish new areas of production (Ayerza, 2012; Boukandoul et al., 2018).

The seed quality can be evaluated by image analysis used to check for seed damage or to evaluate the seed quality of several species. It is a promising technique because it is fast and nondestructive, therefore allowing the performance of physiological tests on the examined material (Menezes et al., 2012).

X-ray tests have been recommended as a promising technique for the study of forest seeds, contributing to their quality control by permitting the selection and disposal of seeds with poor physical and physiological quality (Albuquerque \& Guimarães, 2008).

$\mathrm{X}$-ray testing is widely used for certain species, such as Lithraea molleoides (Vell.) Engl., the seeds of which have been imaged to detect embryo damage or abnormalities and to correlate these abnormalities with germination test results. The method was found to be effective for assessing seed quality (Machado \& Cícero, 2003).

In addition to the physiological quality of seeds, seed health also has to be considered. To obtain vigorous seedlings, it is necessary to use healthy seeds because seeds may serve as a vehicle for spreading pathogens capable of decreasing or even eliminating populations (Mendes et al., 2011).

A test of seed health can determine the health status of a seed sample and, consequently, the status of a seed lot, providing information that can be used to compare the quality of different seed lots or determine their uses.

Several pathogenic microorganisms may be associated with seeds from forest species. The most frequent damage caused by fungi appears in the form of necrotic spots, discoloration of seed shells, malformations or rotting. This damage can cause decreased vigor and germination potential as well as problems with seedling formation and can constitute the primary foci of infection in greenhouses or in the field (Oliveira et al., 2011).

Methods for the detection of fungi in seeds include the visual analysis of samples and infected fractions, the microscopic analysis of suspensions obtained from the washing of seeds, the examination of embryos, the paper towel method, incubation in standard culture media or in semiselective media and sowing on absorbent filter paper (blotter test). In most cases, the results are confirmed through microscope observations (Barrocas \& Machado, 2010).

The fungiassociated with seeds can cause damping-off during seedling establishment in the field. Knowledge regarding fungal pathogenicity in moringa seeds is limited, and an investment in additional research is needed to achieve viable results. This knowledge is necessary because the occurrence of fungi in moringa seeds may inhibit the establishment of seedlings in the field if the seeds are not treated with the recommended fungicide.

The goals of the present study were to analyze the internal morphology of moringa seeds of two trees using $X$-ray tests and to identify their associated fungi using the blotter test.

\section{Materials and Methods}

The study was conducted at the Seed Analysis and Seed Pathology Laboratories of the Federal University of Lavras (Universidade Federal de Lavras), Minas Gerais, Brazil, in the period from April to June 2013. The moringa seeds of the two different trees were collected in Aracaju, state of Sergipe, Brazil.

For the evaluation of external seed morphology, images were obtained using the PRO version of the Seed Analysis System $\left(S A S^{\circledR}\right)$. The seed area, roundness, maximum and minimum diameter, sphericity, contour irregularity, and perimeter were analyzed using 100 seeds per tree. These data were accessed using the image analysis.

For the examination of internal seed morphology, the seeds were subjected to X-ray analysis using a Faxitron HP MX-20 device (Faxitron X-ray Corp, Tucson, AZ, USA) operated at $22 \mathrm{kv}$, with an approximate exposure time of $14.8 \mathrm{~s}$ according to an automatic calibration of the equipment. Eight replicates of 25 seeds were 
used, for a total of 200 seeds per tree. The results of the X-ray analysis were used to define the seed categories.

Following the X-ray-based classification, the seeds were subjected to germination tests, with four replicates of 25 seeds per category. The tests were conducted in a germination chamber at $25^{\circ} \mathrm{C}$ using germitest paper, which was moistened with 2.5 times the paper weight using distilled water. The germination results were evaluated on day seven (first germination count) and fourteen following the beginning of the test and expressed as the percentage of seedlings that appeared normal according to the Rules for Seed Analysis (Brasil, 2009).

The health of 200 seeds per tree was evaluated according to the modified blotter test using 2,4-dichlorophenoxyacetic acid (2,4-D) after dividing the seeds of each tree into eight replicates of 25 seeds each. The seeds were placed in both sterile Petri dishes on three layers of absorbent filter paper moistened with 2.5 times of the paper weight with distilled water, 2,4-D (10 ppm) and agar. The Petri dishes were placed in seed germination chambers at $20^{\circ} \mathrm{C}$ under a 12 hour light/12-hour dark photoperiod for seven days. At the end of this period, the presence of microorganisms in the seeds was evaluated using a dissecting microscope to visualize the fungal morphology. The results obtained were expressed as the percentage incidence of each observed microorganism.

Using SISVAR ${ }^{\circledR}$ software (Ferreira, 2011), the data were subjected to an analysis of variance employing the $\mathrm{F}$ test followed by the Scott-Knott test at $p<0.05$.

\section{Results and Discussion}

Significant differences in seed area, maximum and minimum diameter and perimeter were observed between the two studied trees, for both trees the round geometry of seeds were observed; and the average values observed are shown in Table 1.

Table 1. Average area $\left(\mathrm{cm}^{2}\right)$, roundness, maximum diameter $(\mathrm{cm})$, minimum diameter $(\mathrm{cm})$, sphericity, contour irregularity and perimeter $(\mathrm{cm})$ of seeds from two Moringa oleifera Lam. trees

\begin{tabular}{lccc}
\hline Geometry & Tree 01 & Tree 02 & CV (\%) \\
\hline Area $\left(\mathrm{cm}^{2}\right)$ & $0.88 \mathrm{a}$ & $0.79 \mathrm{~b}$ & 12.17 \\
Roundness & $0.84 \mathrm{a}$ & $0.84 \mathrm{a}$ & 6.21 \\
Maximum diameter $(\mathrm{cm})$ & $1.15 \mathrm{a}$ & $1.09 \mathrm{~b}$ & 6.55 \\
Minimum diameter $(\mathrm{cm})$ & $0.95 \mathrm{a}$ & $0.90 \mathrm{~b}$ & 7.15 \\
Sphericity & $16.10 \mathrm{a}$ & $15.92 \mathrm{a}$ & 7.56 \\
Contour irregularity & $0.03 \mathrm{a}$ & $0.03 \mathrm{a}$ & 30.39 \\
Perimeter $(\mathrm{cm})$ & $3.75 \mathrm{a}$ & $3.53 \mathrm{~b}$ & 6.50 \\
\hline Averages within rows followed by the same letter are not significantly different according to the Scott-Knott test at p<0.05.
\end{tabular}

Studies of seed physical characteristics are very important for the development of agricultural machinery and equipment (Melo et al., 2007). These characteristics can also contribute to the characterization of trees and the adjustment of equipment for seed improvement and so to increase product quality.

In this sense, Devilla et al. (2010) studied the physical properties of castor beans seeds (Ricinus communis L.) and reported that the Paraguaçu cultivar had higher values than the Guarani IAC-266, IAC-80, Comum, Rajada, Branquinha and Nordestina cultivars. There are no reports for the seeds of moringa cultivars.

For the seed image analysis, the seeds were divided into the following categories according to their internal morphology: (1) full and well formed, (2) with internal space and malformed and (3) stained or (4) damaged (Figure 1).

The differences observed among the seed categories occurs because of differences in the supply of assimilates during development (Oliveira et al., 2013). The seeds located at the base of the fruit are closer to the photosynthetic source than the ones more distant from the peduncle (Marcos-Filho, 2015). The basally positioned seeds can therefore accumulate greater reserves (Oliveira et al., 2013). The full and well-formed seeds therefore possibly originated from the base of the fruit, which may explain why fewer of these seeds were observed. The seeds from the remaining categories most likely originated at the middle and apical portions of 

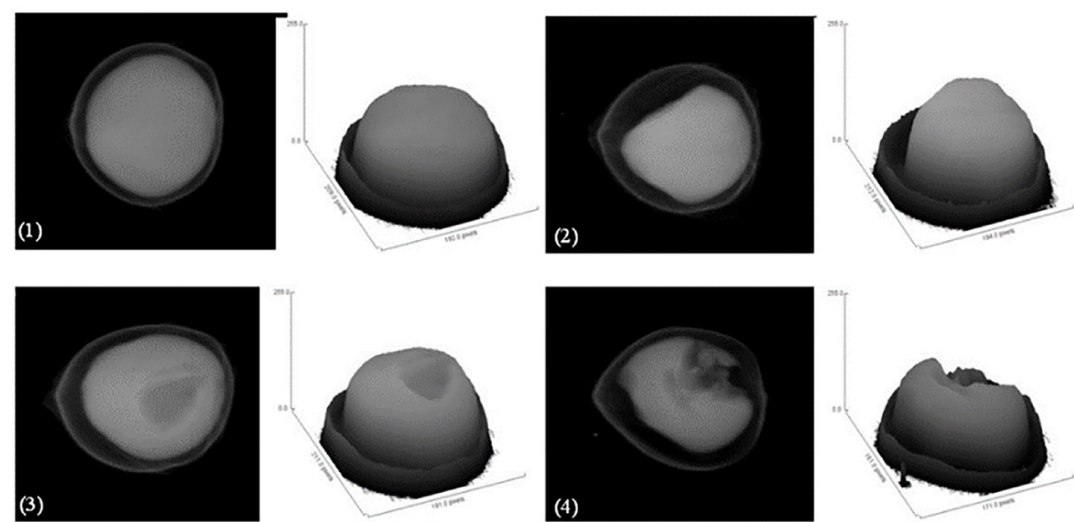

Figure 1. X-rays of Moringa oleifera Lam. seed internal morphology showing seeds that are full and well formed (1), with internal space and malformed (2), stained (3) and damaged (4)
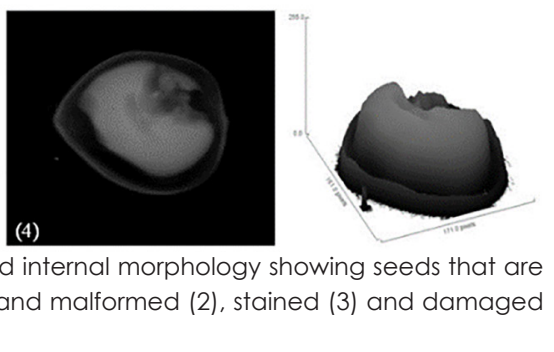

the fruit (Oliveira et al., 2013). For both trees, the seeds in the with internal space and malformed category were the most abundant. This was the only seed category that did not differ significantly between the two trees (Table 2).

It was not possible to identify the seed structures that are essential for seedling development, such as the embryonic axis, which was very small when compared with the seed endosperm. By contrast, it was possible to identify the essential structures of Jatropha curcas seeds using the X-ray test (Pinto et al., 2009).

Table 2. Frequency (\%) by seed category from two Moringa oleifera Lam. trees

\begin{tabular}{lcc}
\hline Category & Tree 01 & Tree 02 \\
\hline Full and well formed & $3.0 \mathrm{a}$ & $14.0 \mathrm{~b}$ \\
With internal space and malformed & $49.5 \mathrm{a}$ & $59.0 \mathrm{a}$ \\
Stained or damaged & $47.5 \mathrm{a}$ & $27.0 \mathrm{~b}$ \\
\hline Averages within rows followed by the same letter are not significantly different according to the Scott-Knott test at $p<0.05$.
\end{tabular}

The number of seeds belonging to the full and well-formed category was insufficient because of the number of seeds evaluable for the tests. For the remaining categories, no difference in germination rate was observed between the (Table 3).

The stained or damaged seeds had higher germination rates (Table 3). Therefore, the stains or damage observed along the cotyledon did not affect the germination of moringa seeds. trees or between the categories within each tree

Table 3. Germination percentage (\%) in two of the three seed morphological categories for seeds from two Moringa oleifera Lam. trees

\begin{tabular}{lcc}
\hline Category & Tree 01 & Tree 02 \\
\hline With internal space and malformed & $69.00 \mathrm{Aa}$ & $54.00 \mathrm{Aa}$ \\
Stained or damaged & $79.00 \mathrm{Aa}$ & $71.25 \mathrm{Aa}$ \\
\hline Averages within rows followed by the same uppercase letter and within columns by the same lowercase letter are not significantly different according to the \\
Scott-Knott test at $p<0.05$.
\end{tabular}

An X-ray test of castor seeds revealed a lower germination rate for partially full and stained or damaged seeds than for full and opaque or stained seeds (Kobori et al., 2012).

The moringa seeds with stains or damage should therefore not be discarded from the lot because their germination is determined by their physiological potential. An earlier X-ray analysis revealed that there is no direct relationship between the presence of stains and a loss of seed quality (Pupim et al., 2008). The stains observed on most moringa seeds are related to small changes in the formation of cotyledons, which do not compromise germination (Figure 2). However, the stains observed in the X-rays, such as the one in Figure 1(3), can be related to the presence of fungi in internal seed structures.

The combination of light and dark tones observed in X-rays is determined by the number of X-rays absorbed by the different seed regions (Ista, 1996). When the internal seed cavity is not completely filled by the embryo and endosperm tissue or when the cavity contains less dense tissue, dark spots are observed on the X-rays 
because there is not enough resistance to block the passage of X-rays through the seed (Gagliardi \& Marcos-Filho, 2011).

During germination, seeds are subjected to factors that can decrease their development potential. Among these factors, the occurrence of microorganisms is a determining factor for seed germination performance (Machado \& Cícero, 2003).
The following microorganisms were identified in the moringa seed health test: Aspergillus niger, Aspergillus flavus, Alternaria sp., Fusarium sp., Penicillium sp. and Phomopsis sp. (Table 4). A difference between the trees was observed for A. niger, Fusarium sp. and Phomopsis sp., with a higher incidence of $A$. niger for tree 1 and of Fusarium sp. and Phomopsis sp. for tree 2.
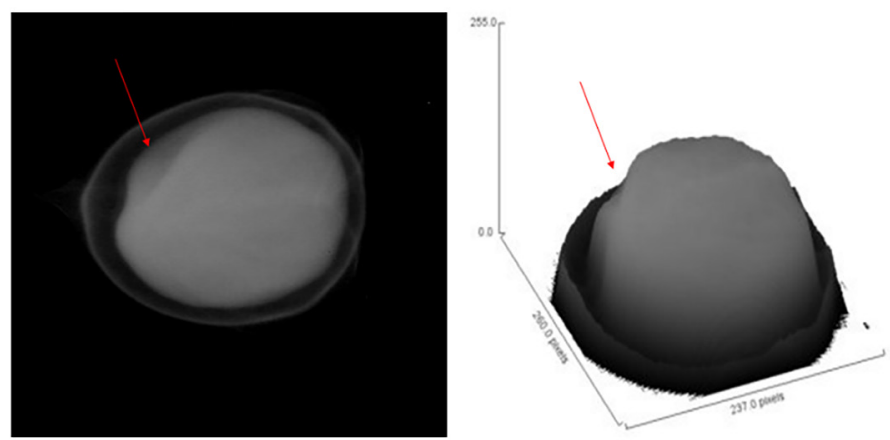

Figure 2. X-ray of a seed of Moringa oleifera Lam. classified as stained based on internal morphology

Table 4. Occurrence (\%) of fungi in seeds from two Moringa oleifera Lam. trees according to the blotter test

\begin{tabular}{lcc}
\hline Fungus & Tree 01 & Tree 02 \\
\hline Aspergillus niger & $97.5 \mathrm{a}$ & $2.5 \mathrm{~b}$ \\
Aspergillus flavus & $17.5 \mathrm{a}$ & $9.5 \mathrm{a}$ \\
Alternaria sp. & $2.0 \mathrm{a}$ & $2.5 \mathrm{a}$ \\
Fusarium sp. & $10.0 \mathrm{a}$ & $18.5 \mathrm{~b}$ \\
Penicillium sp. & $14.0 \mathrm{a}$ & $7.5 \mathrm{a}$ \\
Phomopsis sp. & $29.5 \mathrm{a}$ & $51.0 \mathrm{~b}$ \\
\hline Averages within rows followed by the same letter are not significantly different according to the Scott-Knott test at p<0.05.
\end{tabular}

In some forest species including Leucaena leucocephala Lam., the occurrence of seed-associated microorganisms from such genera as Aspergillus, Penicillium, Nigrospora, Colletotrichum and Fusarium does not interfere with germination (Mendes et al., 2011).

Aspergillus niger is a cosmopolitan saprophyte, which only causes the degradation of plant organs in storage. It becomes detrimental for seeds when seed lots are stored at high humidity (Oliveira et al., 2011). Fusarium species are commonly associated with the seeds of several crops, causing decreased germination and vigor, and belong to the complex of pathogens causing plant damping-off (Kobayasti et al., 2011).

In Myrsine ferruginea, certain potentially pathogenic fungi were observed in both fruit and seeds. Alternaria sp., Colletotrichum sp., Fusarium sp., Macrophomina sp. and Pestalotia sp. were identified; these fungi were possibly transmitted from the fruit to the seeds (Rego et al., 2009).

Phytopathogenic fungi may be associated with seeds in all their production stages. This association is often responsible for a decreased physiological quality of seeds, long distance pathogen dispersal, and pathogen transmission from the seed to the plant, and this relationship provides an efficient means of pathogen survival in direct contact with the host (Machado, 1982).

The seed-associated fungi of the two moringa trees studied were identified and quantified through the health analysis. These fungi can be transported attached to the seed surface, inside the seed or along with inert physical impurities associates with the seed.

These results corroborate the need for seed treatment, those of systemic action, the most recommended in order to obtain healthy seedlings. 


\section{Conclusions}

X-ray tests are valid for the characterization of the internal morphology of moringa seeds. Aspergillus niger, Aspergillus flavus, Alternaria sp., Fusarium sp., Penicillium sp. and Phomopsis sp. fungi occur in moringa seeds.

\section{References}

Albuquerque, K.S., Guimarães, R.M. 2008. Avaliação da qualidade de sementes de sucupira-preta (Bowdichia virgilioides Kunth.) pelo teste de raios X. Ciências Agrotécnica, 32: 1713-1718.

Ayerza, R. (2012). Seed and oil yields of Moringa oleifera variety Periyakalum-1 introduced for oil production in four ecosystems of South America. Industrial Crops \& Products, 36: 70-73.

Barrocas, E.N., Machados, J.C. 2010. Introdução a patologia de sementes e testes convencionais de sanidade de sementes para a detecção de fungos fitopatogênicos. Informativo ABRATES, 20: 74-83.

Brasil. Ministério da Agricultura, Pecuária e Abastecimento. 2009. Regras para Análise de Sementes. Brasília, 398p.

Boukandoul, S., Casal, S., Zaidi, F. 2018. The Potential of Some Moringa Species for Seed Oil Production. Agriculture, 8: 150.

Devilla, I.A., Barbosa, L.S., Reis, R.C., Rei, J.S., Reis, M.C. 2010. Avaliação das Propriedades Físicas da Mamona (Ricinus communis L.) Cultivar Paraguaçu. Revista Agrotecnologia, 1: 89-98.

Ferreira, D.F. 2011 . Sisvar: a computer statistical analysis system. Ciência e Agrotecnologia, 35: 1039-1042.

Gagliardi, B., Marcos-Filho, J. 2011 . Relationship between germination and bell pepper seed structure assessed by the X-ray test. Scientia Agricola, 68: 411-416.

Ista. International Seed Testing Association. ISTA. 1996. International rules for seed testing. Seed Science and Technology 24: Supplement.

Kobayasti, L., Adoriam, A.I., Paiva Neto, V.B., Alves, C.Z., Zuffo, M.C.R. 2011. Incidência de fungos em sementes de pinhão-manso. Pesquisa Agropecuária Tropical, 41: 385-390.

Kobori, N.N., Cicero, S.M., Medina, P.F. 2012 Teste de raios-X na avaliação da qualidade de sementes de mamona. Revista Brasileira de Sementes, 34: 125-133.

Machado, J.C. 1982. Controle de fitopatógenos associados a sementes. Informe Agropecuário,
8: 34-40.

Machado, C.F., Cícero, S.M. 2003. AroeiraBranca' [Lithraea Molleoides (Vell.) Engl. Anacardiaceae] Seed Quality Evaluation by the X-Ray Test. Scientia Agricola, 60: 393-397.

Marcos Filho, J. 2015. Fisiologia de sementes de plantas cultivadas. Piracicaba: FEALQ. 660p.

Melo, K.S., Bezerra, M.S.T., Fernandes, T.K.S., Braga, M.E.D. 2007. Determinação das propriedades físicas da semente de mamona. Revista Educação Agrícola Superior, 22: 54-58.

Mendes, S.S., Mesquita, J.B., Marino, R.H. 2011. Qualidade sanitária de sementes de Leucaena leucocephala (Lam.) de Wit armazenadas em câmara fria. Natural Resources, 1: 15-22.

Menzes, N.L., Cicero, S.M., Villela, F.A., Bortolotto, R.P. 2012. Using X-rays to evaluate fissures in rice seeds dried artificially. Revista Brasileira de Sementes, 34: 70-77.

Mirhashemi, M.S., Mohseni, S., Hasanzadeh, M., Pishvaee, M.S. 2018. Moringa oleifera biomass-tobiodiesel supply chain design: An opportunity to combat desertification in Iran. Journal of Cleaner Production, 203: 313-327.

Oliveira, M.D.M., Nascimento, L.C., Alves, E.U., Gonçalves, E.P., Guedes, R.S., Silva Neto, J.J. 2011. Qualidade sanitária e fisiológica de sementes de Amburana cearensis A.C. Smith submetidas à termoterapia e tratamento químico. Acta Scientiarum, 33: 45-50.

Oliveira, F.A., Oliveira, M.K.T., Silva, R.C.P., Silva, O.M.P., Maia, P.M.E., Cândido, W.S. 2013. Crescimento de mudas de moringa em função da salinidade da água e da posição das sementes nos frutos. Revista Árvore, 37: 79-87.

Pinto, T.L.F., Marcos Filho, J., Forti, V.A., Carvalho, C., Gomes Filho, F.G. 2009. Avaliação da viabilidade de sementes de pinhão-manso pelos testes de tetrazólio e de raios X. Revista Brasileira de Sementes, 31: 95-2001.

Pupim, T.L., Novembre, A.D.L.C., Carvalho, M.L.M., Cicero, S.M. 2008. Adequação do teste de raios $x$ para avaliação da qualidade de sementes de embaúba (Cecropia pachystachya Trec.). Revista Brasileira de Sementes, 30: 28-32.

Rego, S.S., Santos, A.F., Medeiros, A.C.S. 2009. Fungos associados aos frutos e sementes de capororoca (Myrsine ferruginea) Myrsinaceae. Pesquisa Florestal Brasileira, 58: 87-90. 